\title{
The Effect of Local Area Unemployment on Compensating Wage Differentials for Injury Risk
}

\author{
Keith A. Bender* and Hosne Mridha†
}

\begin{abstract}
Compensating wage differential (CWD) theory assumes that workers can always find a job without undesired characteristics, which forces firms with disamenities to pay a CWD. However, a simple theoretical variation of standard CWD theory shows that if there is a probability of job loss due to involuntary unemployment, the CWD is lower. When this probability is proxied by local unemployment rates, we find a downward bias in typical estimated CWDs using cross-sectional data that span many local labor markets. Estimates from the Current Population Survey data show that the bias can be quite large, which in turn impacts the implicit value of injury estimates.
\end{abstract}

JEL Classification: J28, J17, J64

\section{Introduction}

The theory of compensating differentials, as formally described by Rosen (1986) and others, assumes that workers can easily find jobs without undesirable characteristics. With the ease of movement between "clean" and "dirty" jobs, for example, workers will have the incentive to take dirty jobs only when there is a high enough wage premium above the wages for clean jobs to compensate them for the disutility of being in a dirty job. However, labor markets are often in flux, making it sometimes difficult to find jobs, thus generating unemployment. This unemployment can be thought of as impacting the compensating wage differential (CWD) through one of two related pathways. First, firms might exploit increased monopsony power in nonclearing labor markets. The theory of CWD assumes that it is costly to reduce a disamenity, and so firms will avoid, for example, offering a CWD or cleaner jobs if they can. Alternatively, the effect could be explained by looking at worker behavior. If unemployment is involuntary, the expected utility of workers will decrease because there is a chance that they will be unemployed and have lower utility than if they were employed. With this new (and lower) expected utility from being in the labor market, the CWD locus should shift downward. Indeed, if the level of joblessness in labor markets is high, then it is not clear that measured differences

* Department of Economics and Graduate Program in Human Resources and Labor Relations, University of Wisconsin-Milwaukee, PO Box 413, Milwaukee, WI 53201, USA; E-mail kabender@uwm.edu; corresponding author.

$\uparrow$ School of Business, North Carolina Central University, 1801 Fayetteville Street, Durham, NC 27707, USA; E-mail hmridha@nccu.edu.

Thanks to seminar participants at the 2008 Midwestern Economics Association Meetings, North Carolina Central University, University of Aberdeen, and the University of Wisconsin-Milwaukee, and to three anonymous referees, Swarnjit Arora, Christopher Bollinger, Bob Elliott, Hans Hvide, and John Skåtun for helpful comments on earlier drafts of the article.

Received January 2010; accepted December 2010. 
in the wages of clean and dirty jobs accurately describe the true compensating differential for that disamenity. This might be particularly problematic in cross-sectional studies where the unemployment rates in local labor markets across a country might vary substantially.

The fact that unemployment rates are included in studies of CWD is not new. However, the intuitive story given above indicates that there may be a relationship between a CWD and the health of the labor market. Indeed, it is the attempt to isolate this interaction that is the innovation of this article. Using cross-sectional U.S. data on the injury riskiness of jobs and unemployment in metropolitan areas, this study finds that there are strong downward biases in the estimated CWD in metropolitan areas with high levels of unemployment, particularly for males and nonunion workers. These results are robust to a variety of econometric and variable specifications. Finally, the bias is found to affect the value of injury estimates as well. For example, the value of an injury using the standard methodology is less than half than the value of estimates controlling for local unemployment rates. These results indicate that when using cross-sectional data it is important to take into account the level of local unemployment rates, as unemployment impacts the observable compensating wage differential.

\section{Related Literature}

The literature on compensating differentials for risk is very large, and it is beyond the scope of this article to review this literature (for two comprehensive reviews, see Viscusi 1993 and Viscusi and Aldy 2003). In general, the main intuition of compensating differential theory, which has been around for at least as early as the 18th-century writings of Adam Smith, is agreed on. In order to induce workers to take a job with an unpleasant characteristic, the firm needs to pay more, ceteris paribus. To find out how much wages need to increase to compensate for the disamenity, hedonic wage regressions are estimated, controlling for the disamenity as well as other variables that determine wages. The estimated relationship between the disamenity and wages is an estimate of the CWD.

Unfortunately, estimates of CWDs are not particularly robust, often finding negative relationships between the disamenity and wages (that is, jobs with disamenities have lower wages). Many reasons have been given for this: mismeasurement of the disamenity, mismeasurement of wages, endogeneity of wages and the disamenity, differing preferences for the disamenity, and even an invalidation of neoclassical models of the labor market, among others. However, the literature has not yet focused on one of the basic assumptions of the theory of CWD, namely, that firms are forced to pay a CWD because the labor market is working efficiently. If firms do not pay more for a disamenity, then a tight labor market will guarantee that workers will take a job with an employer that does not have the disamenity. On the other hand, if the labor market is not tight, the market discipline will not be there to force firms to pay more to workers for the disamenity, and workers will have no choice but to take a job (or be unemployed). Empirically, this problem will be most pronounced in cross-sectional data where workers are spread across (potentially many) different local labor markets, which vary in their ability to clear.

Although this issue is detailed below, the implication of this is that some measure of labor market tightness should be included in estimates of CWDs. Obviously one such proxy is the unemployment rate. There have been a series of articles that have put unemployment in their 
hedonic wage equations. However, the focus of these articles has been on finding a compensating differential for job insecurity. The intuitive explanation in this case is that in order to induce workers to jobs in which there is little job security, employers of these jobs will pay more, ceteris paribus; this has been the focus of many articles, such as Todaro (1969), Harris and Todaro (1970), Hutchens (1983), Abowd and Ashenfelter (1984), Topel (1984), Hamermesh and Wolfe (1990), Hatton and Williamson (1991), Winter-Ebmer (2001), Assad and Tunali (2002), and Averett, Bodenhorn, and Staisiunas (2005), as well as others. They are similar in that they generally include the industry and/or occupation unemployment rate as a regressor in the hedonic wage regression (although Hamermesh and Wolfe, 1990, focus on the duration of unemployment). Indeed, in meta-analyses of CWD for injury and fatality risk, Mrozek and Taylor (2002) and Viscusi and Aldy (2003) also include the unemployment rate as a regressor. It is unclear whether they do this to capture a CWD for risk (as the above referenced articles attempt to do) or to control for local labor market effects. However, it is clear that none of these articles have an explicit discussion that the unemployment rate will affect the CWD for other types of disamenities.

There are several articles that are more closely related to this article in that they indicate that unemployment could play a role in the compensating differential for injury, though none empirically test what the impact of unemployment on estimated compensating differentials would be. First, although they do not explicitly address unemployment, Dorman and Hagstrom (1998) find that noncompetitive labor markets (proxied by union bargaining and discrimination) tend to diminish compensating differentials for dangerous work. Purse (2004) states that nonclearing labor markets will diminish the compensating differential for risk, although Purse does not directly test for whether this is true or how large the bias might be. Lang and Majumdar (2004) offer an interesting theoretical model that allows for search frictions and derives conditions where salary may not be tied to disamenities for jobs.

The most closely related article is Hamermesh and Wolfe (1990), who also investigate the interactions between unemployment and injury risk. However, their article differs from the current article in two important aspects. First, the theoretical motivation for investigating the linkage is different, because the focus here is on the effect of local labor market conditions (as proxied by the unemployment rate) on the CWD for injury risk, while Hamermesh and Wolfe (1990) focus on the fact that it is the duration of the loss of the job due to injury that generates the true CWD for job insecurity, although that amount differs depending on whether or not the unemployment is cyclical. Second, the empirical test of the theory differs. Hamermesh and Wolfe (1990) include unemployment incidence and duration at the industry level with no interactions with injury risk, while the current article examines the effect of local unemployment at the metropolitan statistical area (MSA) level allowing for interactions with injury risk as detailed in the next section.

\section{The Effect of Unemployment on Compensating Differentials for Injury Risk}

\section{A Simple Theoretical Framework}

The theory of compensating differentials and tests to estimate it in the context of compensation for injury risk assume that the labor market clears, that is, that there is relatively 
little unemployment. This section discusses a simple example to show that if there is unemployment in the labor market (that is, some positive probability that people in the labor force will have no job), this can adversely affect the compensating differential for risk and cause it to be lower than what the standard model of compensating differentials would indicate.

We could model this from either the firm or worker standpoint. As mentioned above, one way that the CWD for injury risk can be forced down is that when involuntary unemployment increases, monopsonistic power by firms could increase. If this is the case, then it might be useful to model the effects from the firm's point of view. However, as Manning (2003, chapter 9) indicates, involuntary unemployment and monopsony need not be related, namely, that one could have involuntary unemployment even when there is no monopsony. Therefore, since what is really driving this reduction in the CWD is the lower utility that is associated with involuntary unemployment, the more general way to analyze this issue is from the worker's point of view. ${ }^{1}$

Thus, we follow the standard worker preferences model outlined in Viscusi and Aldy (2003). For a von Neumann-Morgenstern expected utility model with state-dependent utility functions, we define three utility functions. First, $U(w)$ is the utility of a healthy worker with wage $w$. Second, $V(w)$ is the utility of an unhealthy worker (i.e., one that has been injured). Similar to Viscusi and Aldy (2003), we assume that workers' compensation in the case of an injury is a function of the wage, making $V(\cdot)$ a function of the wage. Third, we define utility while not working (i.e., unemployment) as $B(w)$. As with $V(\cdot)$, we also assume $B(\cdot)$ is a function of the wage (perhaps because of unemployment benefits tied to wages or accumulated savings or welfare payments that are tied to the wage level in the economy). Intuitively it makes sense to assume that healthy work is preferred to injured work $(U(w)>V(w))$ and that the expected utility of work is greater than the utility given in unemployment, that is, $(1-p) U(w)+p V(w)>B(w)$ for a given $w$ (otherwise people would be voluntarily unemployed). Finally, the marginal utility of income is positive in all three states, such that $U^{\prime}(w)>0, V^{\prime}(w)>0$, and $B^{\prime}(w)>0$.

Before evaluating the model, a few comments need to be made about how unemployment is viewed in this particular model. The assumptions imply that unemployment is exogenously determined and involuntary with the implication that it is better to be employed than unemployed. This is certainly the driving consideration of the literature that focuses on compensating differentials for job insecurity as proxied by industry or occupation unemployment rates discussed above. If the prospect of unemployment did not generate lower utility, then no compensating differential would need to be paid. Therefore, we are simply relying on this previous literature for guidance on how to interpret unemployment. ${ }^{2}$

On the other hand, while unemployment is modeled as a state where utility is lower, the effect of unemployment is different here than in the literature on job insecurity. In that literature, for a given health of the local labor market, firms with a relatively high level of job insecurity (i.e., high industry or occupation unemployment) will have to pay a compensating

\footnotetext{
${ }^{1}$ Of course, if there is some monopsony power by firms, then the CWD will be even lower. Unfortunately, we cannot distinguish between the effect of monopsony and involuntary unemployment on lowering the CWD in high unemployment areas.

${ }^{2}$ Obviously, this is not the only interpretation of unemployment, since there are theoretical models of equilibrium unemployment. Intuitively, in this case, firms are still required to pay a compensating differential for risk because, if they do not, then workers will voluntarily be unemployed, and so there would be no interaction between unemployment and CWD for injury risk as implied by Equation 6 and by the coefficient, $\beta_{4}$, in Equation 8 .
} 


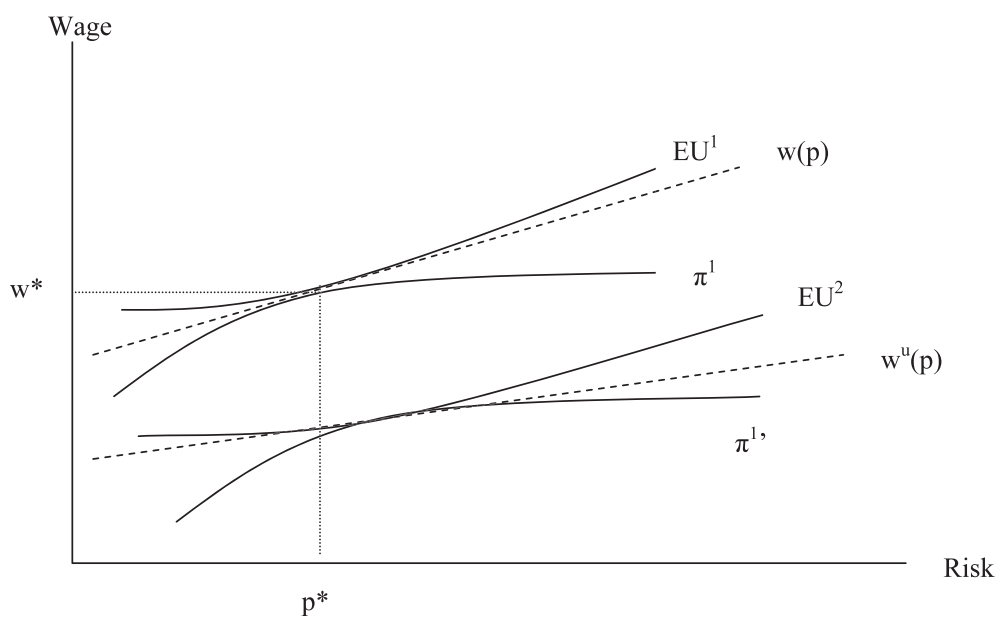

Figure 1. Compensating Wage Differential Locus without and with Unemployment

differential for that relatively high insecurity. Conversely, we are trying to measure what happens when there are changes in the local labor market - that is, when the unemployment rate increases for all individuals. In that case, firms in general do not need to pay a compensating differential. This is modeled by having $B(w)$ lower than the expected utility of work.

A standard analysis of compensating differentials with no unemployment focuses on determining the relationship between wages and the risk of an injury (denoted by $p$ ) that maximizes expected utility. When there are tangencies between the expected utility of workers and expected profits by firm, the locus of all such tangencies generates the market wage-risk tradeoff, denoted $w(p)$ in Figure 1. As Viscusi and Aldy (2003, p. 8) show, for each worker, all wage-risk combinations for each level of expected utility $Z$ must satisfy the following equation:

$$
Z=(1-p) U(w)+p V(w) .
$$

The tradeoff between risk and wages for a given level of expected utility (i.e., the indifference curve) is given by the expression

$$
\frac{d w}{d p}=-\frac{Z_{p}}{Z_{w}}=\frac{U(w)-V(w)}{(1-p) U^{\prime}(w)+p V^{\prime}(w)}>0 .
$$

The implication of this is that for an increase in risk $p$, there must be a corresponding increase in wages to make an individual as well off.

With the introduction of involuntary unemployment, however, this relationship is weakened. In addition to the framework above, assume that there is some probability $u$ that a person will not get a job, that is, be involuntarily unemployed. In this case, expected utility $Z^{u}$ becomes

$$
Z^{u}=(1-u)[(1-p) U(w)+p V(w)]+u B(w) .
$$

Note that now for every wage and risk combination, expected utility is lower (a movement from 
$\mathrm{EU}^{1}$ to $E \mathrm{U}^{2}$ in Figure 1), meaning that workers are likely worse off and firms are likely better off. The indifference curves in this case are given by

$$
\left(\frac{d w}{d p}\right)^{u}=-\frac{Z_{p}^{u}}{Z_{w}^{u}}=\frac{(1-u)[U(w)-V(w)]}{(1-u)\left[(1-p) U^{\prime}(w)+p V^{\prime}(w)\right]+u B^{\prime}(w)}>0 .
$$

There are two key relationships to note here. First, there is still a compensating differential because workers need to be compensated for increased risk (unless $u=1$, when the slope is zero). Second, while this is the case, as $u$ approaches 1, that is, as the probability of unemployment increases, the slope of the indifference curve for each wage and risk combination gets flatter compared to the full employment $(u=0)$ case. This can be seen by differencing Equations 3 and 4, which gives the following expression:

$$
\begin{aligned}
\frac{d w}{d p} & -\left(\frac{d w}{d p}\right)^{u} \\
& =\frac{[U(w)-V(w)] u B^{\prime}(w)}{\left[(1-p) U^{\prime}(w)+p V^{\prime}(w)\right]\left[(1-u)\left[(1-p) U^{\prime}(w)+p V^{\prime}(w)\right]+u B^{\prime}(w)\right]}>0 .
\end{aligned}
$$

Since this term is positive, the wage-risk tradeoff for each level of risk is lower when unemployment is present. That is, there will be a reduction in expected utility for each level of risk, such as a shift from $\mathrm{EU}^{1}$ to $\mathrm{EU}^{2}$ in Figure 1.

However, this is not the only expression of interest from this simple model. We might expect that the shape of the indifference curve of expected utility will shift as well. If we take the derivative of Equation 4 with respect to the unemployment rate $u$ we find the following expression:

$$
\begin{aligned}
\frac{\left(\frac{d w}{d p}\right)^{u}}{d u} & =\frac{-u[U(w)-V(w)]}{(1-u)\left[(1-p) U^{\prime}(w)+p V^{\prime}(w)\right]+u B^{\prime}(w)} \\
& -\frac{(1-u)[U(w)-V(w)]\left[B^{\prime}(w)-\left[(1-p) U^{\prime}(w)+p V^{\prime}(w)\right]\right]}{\left[(1-u)\left[(1-p) U^{\prime}(w)+p V^{\prime}(w)\right]+u B^{\prime}(w)\right]^{2}} \\
& =\frac{-B(w)}{\left[(1-u)\left[(1-p) U^{\prime}(w)+p V^{\prime}(w)\right]+u B^{\prime}(w)\right]^{2}}<0 .
\end{aligned}
$$

Since this derivative is negative, it shows that the slope of the indifference curve at each wagerisk point decreases as the unemployment rate increases. Since the $w(p)$ locus is tangent to the indifference curves, then at each level of $p$, the $w^{u}(p)$ relationship will likely have a smaller slope than the compensating differential relationship in the standard case. ${ }^{3}$

\footnotetext{
${ }^{3}$ Technically this does not have to be the case. If the firm's isoprofit line $\pi^{1}$ moves far enough to the right, then the $w^{u}(p)$ line might be more steeply sloped than the $w(p)$ locus. This would imply that it is very expensive for firms to reduce injury risk relative to cutting wages, given the large move to the right when profits increase. Although this is possible, it is not probable, particularly when firms are large, since a reduction of wages would likely be a more important source for increasing profits. Of course, the effect could be pinned down with more explicit structure on the (iso-) profit functions of firms, but to keep the model as general as possible, we will not explicitly derive this. Note, however, that there is no such restriction on the empirical specification below, and so the empirical relationship embodied by $\beta_{4}$ in Equation 8 would be positive if the combination of unemployment and firm reactions cause the compensating differential line to increase.
} 


\section{Empirical Implications}

Most empirical estimates of $w(p)$ involve a hedonic wage regression that typically takes the form of

$$
w_{i}=\alpha+\beta_{1} X_{i}+\beta_{2} J_{i}+\beta_{3} p_{i}+\varepsilon_{i}
$$

where for person $i, w$ is the $(\log )$ wage, $X$ is a vector of personal characteristics, $J$ is a vector of job characteristics, $p$ is a measure of risk (fatal, nonfatal or both), ${ }^{4} \varepsilon$ is an iid random error term, and $\beta_{1}, \beta_{2}$, and $\beta_{3}$ are parameter vectors to be estimated. In this formulation, the coefficient $\beta_{3}$ is an estimate of the compensating differential for injury risk. As Viscusi and Aldy (2003) note, there have been many variations of estimating Equation 7 in the literature. Most notably there may be interactions between risk and personal characteristics, such as gender, age, and union status, to allow for differing compensating differentials by these characteristics. Therefore, estimates of this basic equation (and the one discussed below) will be examined by these different characteristics of the population.

From Equations 5 and 6, however, we might think that a hedonic regression of Equation 7 would lead to an underestimate of $\beta_{3}$, if workers are located in labor markets where the unemployment rate varies across labor markets (as is likely to be the case in large national surveys). On the one hand, Equation 5 indicates that unemployment causes a shift effect, impacting wages directly echoing the previous literature on CWD for job insecurity. However, the key point of this article is summarized in Equation 6, which implies that the CWD locus itself depends on the unemployment rate. To correct for this bias, Equations 5 and 6 indicate that the following variable specification should be implemented:

$$
w_{i}=\alpha+\beta_{1} X_{i}+\beta_{2} J_{i}+\beta_{3}^{\prime} p_{i}+\beta_{4} p_{i} \times U R_{i}+\beta_{5} U R_{i}+\varepsilon_{i},
$$

where UR is the unemployment rate for worker $i$ 's local region. The new coefficient $\beta_{3}^{\prime}$ is now the unbiased compensating differential, that is, the compensating differential when the unemployment rate is zero. $\beta_{4}$ shows how the compensating differential for risk changes when unemployment rates increase. From Equation 6 , it is expected that $\beta_{4}$ should have a negative sign. It is unclear what the sign of $\beta_{5}$ will be. As mentioned above, if the unemployment rate is proxying for job insecurity, then the sign should be positive. On the other hand, research on the wage curve from Blanchflower and Oswald (1994) would indicate a negative sign. This view is primarily motivated by a noncompetitive theory of the labor market such as monopsony power by firms (similar to the intuition of the model discussed above), so that when unemployment rates are high, individuals lower their reservation wages, causing the equilibrium wage to fall with high unemployment. Since the unemployment rate is measured at the MSA level rather than by industry or occupation unemployment as the CWD for job insecurity literature often uses, it is more likely to be the latter, but no restrictions are placed on the estimated sign of the coefficient.

\footnotetext{
${ }^{4}$ In this article we choose to focus on the CWD for nonfatal risk. While including fatal risk would be an interesting extension, we want to focus on compensating for one type of risk. Obviously there might be a correlation between the two, but as a recent article by Sandy and Elliott (2005) shows, the inclusion of fatal risk does not change the estimated CWD for nonfatal illness significantly.
} 


\section{Data}

If unemployment affects the measured compensating differential for injury risk, it is most likely to be identified in data from labor markets that have different levels of unemployment rates. As it happens, many of the studies that investigate compensating differentials use such cross-sectional data. Therefore, we follow this convention to examine the role of unemployment on CWD for risk. Below we detail the data that we employ.

\section{Demographic Data}

Individual-level data come from the 1996-2001 March Current Population Survey (CPS). ${ }^{5}$ Average hourly wage and demographic information are taken from the CPS to form a sample of workers. We control for a set of regressors standard in the literature: gender, marital status, veteran status, race, education, region of residence, age, age squared, and indicators for twodigit occupation, year, and the metropolitan area in which respondents live.

\section{Unemployment Rate Data}

A separate sample is taken from the CPS for each of these years that includes both working and unemployed individuals. From this sample, we calculate the unemployment rates for the 242 metropolitan areas identified in the CPS in each year. These metropolitan-specific unemployment rates are then merged with the worker dataset and are used to control for local labor market conditions. In the initial estimates, therefore, only those who live in one of the metropolitan areas are included in the sample.

\section{Injury Risk Data}

Finally, we merge injury and illness data from the Bureau of Labor Statistics (BLS) at the three-digit industry level. ${ }^{6}$ These data provide an incidence rate of yearly cases of lost workdays due to injury or illness at the job per 100 full-time workers, by industry. It should be noted that the CWD literature has found that the use of industry (or occupational) injury rates are subject to measurement error (see, for example, Sandy et al. 2001 and Black and Kniesner 2003). Although we could use either or both measures of injury risk, we focus only on the former not only for the sake of brevity, but also because our focus is to see if ignoring local labor market conditions affects the CWD for risk. It is unclear that the direction of the bias would be altered by the measurement error, although the point estimate may be. Ultimately our goal here is to

\footnotetext{
${ }^{5}$ CPS observations which have imputed earnings were deleted from the data used in this study because of the biases noted in Hirsch and Schumacher (2004) and Bollinger and Hirsch (2006). However, leaving in the imputed earnings does not change the results appreciably.

${ }^{6}$ A complicating issue associated with the use of BLS incidence data is that they are reported at the three-digit Standard Industrial Classification (SIC) code, while the March CPS industry codes are based on the detailed Census industry code. However, the BLS publishes a correspondence between the SIC and the Census code. For the most part, these are one-to-one correspondences; where there are not, employment by three-digit SIC code was used to weight the incidence rates to obtain an incidence rate for the Census code. The only worker group excluded from the merged data set is individuals employed in public administration. Their exclusion arises because the BLS does not report risk information for this group of workers.
} 
use a very standard CWD empirical specification to see if there is evidence of the theoretical prediction.

After dropping missing values of the variables and those who do not live in a metropolitan area, the sample of workers comprises of 42,429 individuals. Descriptive statistics of the sample and various subsamples are given in Appendix 1.

\section{Results}

\section{Estimates of Compensating Differentials for Injury Risk}

As a first step, we estimate a "Simple" CWD regression, one that does not use any information on unemployment rates, but one that controls for the set of regressors discussed above. $^{7}$ The estimated coefficient on the injury risk variable, reported in the first row of Table 1, shows that there is a log wage increase of $0.0026 \log$ points (approximately $0.26 \%$ ) when the risk rate increases by one unit - a small but statistically significant compensating differential for risk. The second row reports the estimate of the CWD for risk when the local unemployment rate is included as a regressor. The coefficient is little changed from a "Simple" specification, while the coefficient on the unemployment rate (the standard measure of job insecurity) is negative but insignificantly different from zero. The third row of Table 1 presents estimates of the model suggested by the theoretical model discussed above, namely, one that interacts risk and unemployment. As expected, the coefficient on this interaction is statistically significant and negative at -0.0007 (approximately a $0.1 \%$ reduction in the hourly wage for every percentage point increase in the unemployment rate). On the other hand, the estimated CWD coefficient on risk increases substantially from 0.0026 to 0.0057 , showing the large negative bias on the CWD when the interaction of unemployment rates and injury rates is not controlled for. The coefficient on the unemployment rate is now positive, but it is still statistically insignificant.

The literature on CWD has also focused on estimating the CWD by different subgroups of the population. While there are many comparisons, we focus on three common subgroups: gender, union/nonunion status, and age. The rest of Table 1 reports the estimated CWD for each of these groups for both the "Simple" as well as the "Interacted" model.

In the "Simple" model, both males and females have a positive CWD, although only for males is the coefficient statistically significant. However, when the "Interacted" model is

\footnotetext{
${ }^{7}$ Because of the spatial element introduced by the regional unemployment rates, fixed effects for each metropolitan area are included in each regression to pick up other specific factors that might impact wages across metropolitan areas (such as compensating differentials for local disamenities as in Berger, Blomquist, and Peter 2008 and differences in state laws regarding worker compensation insurance). Selected results are reported in the tables, but full results are available from the authors. Note that because we have many observations in the same metropolitan area that defines our unemployment rates, the standard errors may suffer from clustering. However, because we are controlling for a fixed effect for each metropolitan area and our number of clusters is small relative to the number of observations within many clusters, we follow Wooldridge (2007, pp. 7-8), who cautions using a cluster-robust correction to standard errors since it may be "very conservative when it need not be" (p. 8). Indeed, estimates of standard errors clustered on metropolitan area in the fixed effects model confirm this with almost all $t$-statistics falling below the threshold for statistical significance. Therefore, the results below follow the standard inference in fixed effects models. It is important to note, however, that this issue does not affect the coefficient estimates, which is still an important implication of the theoretical model.
} 
Table 1. Estimates of CWD by Subsample

\begin{tabular}{|c|c|c|c|c|}
\hline \multirow[b]{2}{*}{ Sample } & \multirow[b]{2}{*}{ Model } & \multicolumn{3}{|c|}{ Coefficient on } \\
\hline & & Risk & $\begin{array}{c}\text { Risk*Metro } \\
\text { Unemployment Rate }\end{array}$ & $\begin{array}{c}\text { Metro } \\
\text { Unemployment Rate }\end{array}$ \\
\hline \multirow[t]{3}{*}{ Full } & Simple & $\begin{array}{l}0.0026^{* * *} \\
(3.78)\end{array}$ & & \\
\hline & $\begin{array}{l}\text { Simple with } \\
\text { unemployment rate }\end{array}$ & $\begin{array}{l}0.0026^{* *} \\
(3.78)\end{array}$ & & $\begin{array}{l}-0.0015 \\
(-0.69)\end{array}$ \\
\hline & Interacted & $\begin{array}{l}0.0057 * * * \\
(3.43)\end{array}$ & $\begin{array}{l}-0.0007^{* *} \\
(-2.07)\end{array}$ & $\begin{array}{l}0.0031 \\
(0.98)\end{array}$ \\
\hline \multirow[t]{2}{*}{ Male } & Simple & $\begin{array}{l}0.0027 * * * \\
(2.88)\end{array}$ & & \\
\hline & Interacted & $\begin{array}{l}0.0082 * * * \\
(3.58)\end{array}$ & $\begin{array}{l}-0.0013^{* * *} \\
(-2.63)\end{array}$ & $\begin{array}{l}0.0039 \\
(0.85)\end{array}$ \\
\hline \multirow[t]{2}{*}{ Female } & Simple & $\begin{array}{l}0.0008 \\
(0.86)\end{array}$ & & \\
\hline & Interacted & $\begin{array}{l}0.0016 \\
(0.65)\end{array}$ & $\begin{array}{l}-0.0002 \\
(-0.33)\end{array}$ & $\begin{array}{l}0.0018 \\
(0.42)\end{array}$ \\
\hline \multirow[t]{2}{*}{$\begin{array}{l}\text { Union } \\
\text { members }\end{array}$} & Simple & $\begin{array}{l}0.0046^{* * *} \\
(2.91)\end{array}$ & & \\
\hline & Interacted & $\begin{array}{l}0.0050^{*} \\
(1.27)\end{array}$ & $\begin{array}{l}-0.0001 \\
(-0.11)\end{array}$ & $\begin{array}{l}-0.0073 \\
(-0.91)\end{array}$ \\
\hline \multirow[t]{2}{*}{ Nonunion } & Simple & $\begin{array}{l}0.0005 \\
(0.74)\end{array}$ & & \\
\hline & Interacted & $\begin{array}{l}0.0048^{* * *} \\
(2.66)\end{array}$ & $\begin{array}{l}-0.0010^{* * *} \\
(-2.58)\end{array}$ & $\begin{array}{l}0.0042 \\
(1.23)\end{array}$ \\
\hline \multirow[t]{2}{*}{ Age: 16-34 } & Simple & $\begin{array}{l}-5.10 \mathrm{E}-6 \\
(-0.01)\end{array}$ & & \\
\hline & Interacted & $\begin{array}{l}0.0012 \\
(0.46)\end{array}$ & $\begin{array}{l}-0.0003 \\
(-0.51)\end{array}$ & $\begin{array}{l}-0.0009 \\
(-0.19)\end{array}$ \\
\hline \multirow[t]{2}{*}{ Age: $35-50$} & Simple & $\begin{array}{l}0.0018^{*} \\
(1.75)\end{array}$ & & \\
\hline & Interacted & $\begin{array}{l}0.0057^{* *} \\
(2.18)\end{array}$ & $\begin{array}{l}-0.0009 * \\
(-1.69)\end{array}$ & $\begin{array}{l}0.0065 \\
(1.28)\end{array}$ \\
\hline \multirow[t]{2}{*}{ Age: $51+$} & Simple & $\begin{array}{l}0.0087 * * * \\
(5.25)\end{array}$ & & \\
\hline & Interacted & $\begin{array}{l}0.0160 * * * \\
(3.85)\end{array}$ & $\begin{array}{l}-0.0017^{*} \\
(-1.92)\end{array}$ & $\begin{array}{l}0.0096 \\
(1.22)\end{array}$ \\
\hline
\end{tabular}

The dependent variable is the log of real average wages. Other controls include (when appropriate) gender, marital status, veteran status, race, education, region of residence, age, age squared, indicators for two-digit occupation and year, and metropolitan fixed effects. Regressions are weighted using sample weights. Numbers in parentheses are $t$ statistics.

$*, * *$, and $* * *$ indicate significance at the $10 \%, 5 \%$, and $1 \%$ levels, respectively.

estimated for men, the estimated CWD increases substantially from 0.0027 to 0.0082 , while the interacted variable is -0.0013 and also statistically significant. For women, there are similar qualitative movements in the CWD coefficient and the interaction term is negative, although neither is statistically significant. Although this does not seem to conform to the theory of compensating differences, finding insignificant differentials for women is not unusual in the literature, resulting in many articles focusing on estimating differentials for men only. Various reasons have been given for this from endogeneity bias to mismeasurement of risk (Hersch 1998). 
The next two subsamples of Table 1 present results by union status. There is a relatively large CWD for risk for union workers at 0.0046, unsurprising given earlier research, such as Sandy and Elliott (1996), finds strong CWD for union workers. On the other hand, the estimated CWD for nonunion workers is insignificantly different from zero with a very small point estimate. When the "Interacted" model is estimated, the CWD for risk for both union and nonunion workers becomes nearly equal, increasing to 0.0050 for union workers and 0.0048 for nonunion workers. Interestingly, only in the nonunion case is the interaction term negative and significant $(-0.0010)$, perhaps because unions are better able to protect CWDs obtained for members even in the face of unemployment. ${ }^{8}$

The last three subsamples on the bottom of Table 1 include results when the sample is split into three age categories: $16-34,35-50$, and greater than 50 years. In each case the pattern is similar as in the previous subsamples. The estimates of the CWD are much smaller in the "Simple" model specification, while they are increased in the "Interacted" model, where, as above, the interacted term is negative (although statistically significant at the $10 \%$ level only for the two older age groups). ${ }^{9}$

\section{Robustness Checks}

Although the estimates reported above lend support to the theoretical model, the literature on CWD indicates that there are other potential biases that should be addressed to indicate whether these results are robust to these biases. First among these are corrections for a variety of econometric factors that might bias the coefficients. Second, we examine if the results are possibly a result of how we calculate the unemployment rate and offer two robustness checks to examine if this is a problem.

\section{Endogeneity}

A large portion of the CWD literature stresses the importance of the endogenous relationship between risk, income, and preferences. Since risk is not randomly distributed across workers, people have a choice about the amount of risk to which they are exposed. Therefore such things as preferences for risk or increased income (assuming that safety is a normal good) can impact the amount of risk. The standard correction for this is to estimate a first-stage regression that estimates the level of risk. Central to this is a list of variables included in the risk regression but not included in the wage regression. For this list we rely on the previous literature on CWD and use common instruments: the number of children under six years and under 18 years, nonrespondent income, net worth of a house, and the percentage of

\footnotetext{
${ }^{8}$ This is interesting in the light that, at least under a neoclassical view of unions, unions generate unemployment by increasing wages above the market clearing level. However, in the case of CWD for injury and fatality risks, Sandy and Elliott (1996) and Bender, Mridha, and Peoples (2006) provide some evidence that the union effect on CWD through union voice can actually be efficient. Alternatively, collective bargaining may cause outcomes that are less responsive to the market, forcing firms to pay a compensating differential even in the face of unemployment.

${ }^{9}$ Interestingly, the coefficient on the unemployment rate is statistically insignificant in each of the "Interacted" specifications. It is not clear why this is, since the theoretical model predicts a negative relationship. However, since the metropolitan unemployment rate will be correlated with the industry and occupation unemployment rates in the area (which may proxy for job insecurity and would therefore have a positive influence on wage), the two opposing effects may be canceling each other out.
} 
Table 2. Estimates of CWD Correcting for Endogeneity Using the "Interacted" Model

\begin{tabular}{lccc}
\hline & \multicolumn{3}{c}{ Coefficient on } \\
\cline { 2 - 4 } Sample & Predicted Risk & $\begin{array}{c}\text { Predicted Risk*Metro } \\
\text { Unemployment Rate }\end{array}$ & $\begin{array}{c}\text { Metro } \\
\text { Unemployment Rate }\end{array}$ \\
\hline Full & 0.0037 & $-0.0019^{* * *}$ & $0.0109^{* *}$ \\
Male & $(1.42)$ & $(-3.62)$ & $(2.54)$ \\
& 0.0048 & $-0.0023^{* * *}$ & $0.0111^{*}$ \\
Female & $(1.25)$ & $(-3.01)$ & $(1.71)$ \\
& 0.0002 & $-0.0017^{* *}$ & $0.0110^{*}$ \\
Union members & $(0.05)$ & $(-2.23)$ & $(1.92)$ \\
& 0.0093 & -0.0002 & -0.0091 \\
Nonunion & $(1.27)$ & $(-0.12)$ & $(-0.85)$ \\
& 0.0028 & $-0.0022^{* * *}$ & $0.0120^{* * *}$ \\
Age: $16-34$ & $(1.00)$ & $(-3.90)$ & $(2.63)$ \\
& 0.0065 & $-0.0018^{* *}$ & 0.0088 \\
Age: $35-50$ & $(1.61)$ & $(-2.19)$ & $(1.33)$ \\
& -0.0057 & -0.0013 & 0.0093 \\
Age: $51+$ & $(-1.41)$ & $(-1.63)$ & $(1.40)$ \\
& $0.0172^{* *}$ & $-0.0040^{* * *}$ & $0.0240^{* *}$ \\
& $(2.50)$ & $(-2.91)$ & $(2.34)$ \\
\hline
\end{tabular}

The dependent variable is the log of real average wages. Other controls include (when appropriate) gender, marital status, veteran status, race, education, region of residence, age, age squared, indicators for two-digit occupation and year, and metropolitan fixed effects. Regressions are weighted using sample weights. Numbers in parentheses are $t$ statistics. Risk variables are predicted from a first-stage regression that also controls for number of children under 6 years and under 18 years, nonrespondent income, net worth of house, and percentage of individuals in industry who are managers and who are white-collar workers. First-stage regression results are available from the authors. Standard errors are corrected for generated regressors and robust to heteroskedasticity.

$*, * *$, and $* * *$ indicate significance at the $10 \%, 5 \%$, and $1 \%$ levels, respectively.

individuals in the industry who are managers and white collar workers. ${ }^{10}$ Then risk, predicted from this first stage regression, is used in the place of actual risk to estimate an endogeneitycorrected CWD. ${ }^{11}$

Table 2 contains results from this method, reporting the results from the "Interacted" model. For the full and nearly every subsample, there is a positive CWD (although it is only statistically significant for the oldest age group), and the coefficient on the unemployment rate is now positive and significant for many of the subsamples. In addition, the coefficient on the interacted variable continues to be negative and is significant for each subsample, except in the case of union workers and the middle age group. Standard controls for endogeneity, therefore, do not seem to be driving the results for the unemployment-risk interaction. ${ }^{12}$

\footnotetext{
${ }^{10}$ Similar instruments have been used in Garen (1988), Sandy and Elliott (1996), Sandy et al. (2001), and Bender, Mridha, and Peoples (2006).

${ }^{11}$ Garen (1988) offers a variant of this methodology, sometimes used in this literature. The results from using this methodology do not vary substantially from the more simple results presented here and are available from the authors.

${ }^{12}$ A related form of endogeneity may be the injury rate itself may be affected by the unemployment rate. For example, Robinson (1988) finds this with manufacturing injury rates, theorizing that the cause is a decline in union bargaining power. Looking at a correlation between average injury rates in a MSA and the MSA unemployment rate does show a positive, but small, correlation of 0.16 . Ultimately, however, it is not clear if it is that the injury rate in a particular job has increased or that more people take jobs that have higher than average injury rates because of the bad economy. In the former case, one would have to model an endogenous injury rate from the firm's point of view, while the latter case is one that would be generated by the model discussed in this article.
} 


\section{Unemployment Sample Selection}

Another important form of bias could be the potential that the sample of workers used here is nonrandomly different than the unemployed population, leading to a sample selectivity bias. Our main concern is not so much with the coefficient on the risk variable but with the coefficient on the interaction since that depends upon the unemployment rate. If unemployment sample selection is important, then the bias might be seen most in this interaction variable. We correct for this using the standard maximum likelihood Heckman (1979) correction for sample selectivity. In this empirical methodology, there is a simultaneous equation estimation where one equation is the wage regression and the other regression is the "worker" sample selection regression, which includes workers and the unemployed. The selection regression includes all variables from the wage regression (except for occupation since the unemployed are not currently working) as well as the number of children under 6 and under 18 and household nonwage income as instruments. ${ }^{13}$

The results of this exercise are contained in Table 3 . In general the results are little different than those presented in Tables 1 and 2. There are still a strong positive estimated CWD for injury risk, particularly for the full, male, nonunion, and middle and older age groups, and the coefficient on the unemployment rate is generally positive and statistically significant. The interaction term of risk and unemployment rate, however, remains negative and statistically significant for most of the samples, particularly for males, females (endogeneity corrected), nonunion workers, and younger and older workers (endogeneity corrected), and the middle age workers, even after controlling for unemployment sample selection.

\section{Alternative Methods of Calculating Unemployment Rates}

Central to this study is the calculation of the unemployment rate. The results above use CPS data on labor force attachment in MSAs to calculate a MSA-specific unemployment rate that is recorded for each CPS worker in that MSA. Here we examine whether this method is robust by reporting results using different methodologies to calculate and apply unemployment rates to workers.

First, there may be mismeasurement of unemployment rates for "small" MSAs. Indeed, some MSAs have less than 50 observations in our sample of the CPS, which could generate large variation in measured unemployment rates that is spurious. Therefore as a robustness check we take the largest $51 \mathrm{MSAs}^{14}$ (as defined in our sample) and re-estimate the log wage regressions. Table 4 contains these results. As can be seen, the general pattern of the results does not change from before. In general, there is a positive and statistically significant CWD and coefficient on the MSA unemployment rate for the same subsamples and econometric specifications as above. Likewise, the coefficient on the interacted variable continues to be negative and statistically significant for each sample, except for women and union workers.

\footnotetext{
${ }^{13}$ While strictly not needed in the maximum likelihood Heckman correction (because of the nonlinearity of the correction), instruments help in the correction of sample selection. These latter variables are excluded since they are assumed to affect the unemployment status of individuals but not wages.

${ }^{14}$ These are the largest as defined in our sample. There are at least 244 observations for each MSA - up to a maximum of 1790. The overall sample, however, has been reduced to 26,167 compared to 42,249 when all MSAs are included.
} 
Table 3. Estimates of CWD by Subsamples, Correcting for Unemployment Sample Selectivity

\begin{tabular}{|c|c|c|c|c|}
\hline \multirow[b]{2}{*}{ Sample } & \multirow[b]{2}{*}{ Model } & \multicolumn{3}{|c|}{ Coefficient on } \\
\hline & & Risk & $\begin{array}{c}\text { Risk*Metro } \\
\text { Unemployment Rate }\end{array}$ & $\begin{array}{c}\text { Metro } \\
\text { Unemployment } \\
\text { Rate }\end{array}$ \\
\hline \multirow[t]{2}{*}{ Full } & Interacted & $\begin{array}{l}0.0058^{* * *} \\
(3.52)\end{array}$ & $\begin{array}{l}-0.0007^{* *} \\
(-2.15)\end{array}$ & $\begin{array}{l}0.0032 \\
(1.02)\end{array}$ \\
\hline & $\begin{array}{c}\text { Endogeneity } \\
\text { corrected }\end{array}$ & $\begin{array}{l}0.0038 \\
(1.50)\end{array}$ & $\begin{array}{l}-0.0020 * * * \\
(-4.07)\end{array}$ & $\begin{array}{l}0.0115^{* * *} \\
(2.95)\end{array}$ \\
\hline \multirow[t]{2}{*}{ Male } & Interacted & $\begin{array}{l}0.0083^{* * *} \\
(3.63)\end{array}$ & $\begin{array}{l}-0.0013 * * * \\
(-2.68)\end{array}$ & $\begin{array}{l}0.0040 \\
(0.88)\end{array}$ \\
\hline & $\begin{array}{c}\text { Endogeneity } \\
\text { corrected }\end{array}$ & $\begin{array}{l}0.0045 \\
(1.26)\end{array}$ & $\begin{array}{l}-0.0023^{* * *} \\
(-3.26)\end{array}$ & $\begin{array}{l}0.0113^{*} \\
(1.94)\end{array}$ \\
\hline \multirow[t]{2}{*}{ Female } & Interacted & $\begin{array}{l}0.0017 \\
(0.72)\end{array}$ & $\begin{array}{l}-0.0002 \\
(-0.40)\end{array}$ & $\begin{array}{l}0.0019 \\
(0.44)\end{array}$ \\
\hline & $\begin{array}{c}\text { Endogeneity } \\
\text { corrected }\end{array}$ & $\begin{array}{l}0.0004 \\
(0.12)\end{array}$ & $\begin{array}{l}-0.0019 * * * \\
(-2.64)\end{array}$ & $\begin{array}{l}0.0120 * * \\
(2.26)\end{array}$ \\
\hline \multirow[t]{2}{*}{ Union members } & Interacted & $\begin{array}{l}0.0053 \\
(1.38)\end{array}$ & $\begin{array}{l}-0.0001 \\
(-0.19)\end{array}$ & $\begin{array}{l}-0.0070 \\
(-0.90)\end{array}$ \\
\hline & $\begin{array}{c}\text { Endogeneity } \\
\text { corrected }\end{array}$ & $\begin{array}{l}0.0098 \\
(1.43)\end{array}$ & $\begin{array}{l}0.0001 \\
(0.11)\end{array}$ & $\begin{array}{l}-0.0091 \\
(-0.90)\end{array}$ \\
\hline \multirow[t]{2}{*}{ Nonunion } & Interacted & $\begin{array}{l}0.0049 * * * \\
(2.74)\end{array}$ & $\begin{array}{l}-0.0010^{* * *} \\
(-2.66)\end{array}$ & $\begin{array}{l}0.0043 \\
(1.27)\end{array}$ \\
\hline & $\begin{array}{c}\text { Endogeneity } \\
\text { corrected }\end{array}$ & $\begin{array}{l}0.0028 \\
(1.06)\end{array}$ & $\begin{array}{l}-0.0024 * * * \\
(-4.36)\end{array}$ & $\begin{array}{l}0.0128 * * * \\
(3.08)\end{array}$ \\
\hline \multirow[t]{2}{*}{ Age: $16-34 \#$} & Interacted & $\begin{array}{l}0.0026 \\
(1.05)\end{array}$ & $\begin{array}{l}-0.0006 \\
(-1.11)\end{array}$ & $\begin{array}{l}0.0050 \\
(1.05)\end{array}$ \\
\hline & $\begin{array}{c}\text { Endogeneity } \\
\text { corrected }\end{array}$ & $\begin{array}{l}0.0085^{* *} \\
(2.27)\end{array}$ & $\begin{array}{l}-0.0024 * * * \\
(-3.18)\end{array}$ & $\begin{array}{l}0.0166^{* * * *} \\
(2.81)\end{array}$ \\
\hline \multirow[t]{2}{*}{ Age: $35-50$} & Interacted & $\begin{array}{l}0.0057 * * \\
(2.22)\end{array}$ & $\begin{array}{l}-0.0009^{*} \\
(-1.66)\end{array}$ & $\begin{array}{l}0.0065 \\
(1.30)\end{array}$ \\
\hline & $\begin{array}{c}\text { Endogeneity } \\
\text { corrected }\end{array}$ & $\begin{array}{l}-0.0062 \\
(-1.57)\end{array}$ & $\begin{array}{l}-0.0014^{*} \\
(-1.81)\end{array}$ & $\begin{array}{l}0.0098 \\
(1.59)\end{array}$ \\
\hline \multirow[t]{2}{*}{ Age: $51+\#$} & Interacted & $\begin{array}{l}0.0093^{* *} \\
(2.23)\end{array}$ & $\begin{array}{l}-0.0006 \\
(-0.71)\end{array}$ & $\begin{array}{l}-0.0006 \\
(-0.08)\end{array}$ \\
\hline & $\begin{array}{c}\text { Endogeneity } \\
\text { corrected }\end{array}$ & $\begin{array}{l}0.0150 * * \\
(2.29)\end{array}$ & $\begin{array}{l}-0.0043^{* * *} \\
(-3.19)\end{array}$ & $\begin{array}{l}0.0222^{* *} \\
(2.18)\end{array}$ \\
\hline
\end{tabular}

The dependent variable is the log of real average wages. Other controls include (when appropriate) gender, marital status, veteran status, race, education, region of residence, age, age squared, indicators for two-digit occupation and year, and metropolitan fixed effects. Regressions are weighted using sample weights. Numbers in parentheses are $t$ statistics. Controls for unemployment sample selection using the Heckman (1979) selectivity correction, where the variables included in the selection equation are indicators for the number of children and other household income. Maximum likelihood estimates are reported, except in the subsamples indicated by "\#" where the maximum likelihood estimator did not converge and the Heckman "twostep" estimator was employed. Full results are available upon request. Tests for the independence of the selection and wage equations are rejected for the full, male, female, union, and nonunion samples with chi-squared statistics ranging from 6 to 10 .

$*, * *$, and $* * *$ indicate significance at the $10 \%, 5 \%$, and $1 \%$ levels, respectively.

The second issue involves the sample used. The theoretical model above should apply for any worker, not just those in a MSA. That is, local labor market conditions may affect the CWD for urban as well as rural workers. However, although the MSA unemployment rate is likely a relatively good proxy for the labor market conditions in a MSA, it is not clear how to derive the local unemployment rate for rural workers in the CPS. One 
Table 4. Estimates of CWD by Subsample and Model for Largest 51 Metropolitan Areas

\begin{tabular}{|c|c|c|c|c|}
\hline \multirow[b]{2}{*}{ Sample } & \multirow[b]{2}{*}{ Model } & \multicolumn{3}{|c|}{ Coefficient on } \\
\hline & & Risk & $\begin{array}{c}\text { Risk*Metro } \\
\text { Unemployment Rate }\end{array}$ & $\begin{array}{c}\text { Metro } \\
\text { Unemploymen } \\
\text { Rate }\end{array}$ \\
\hline \multirow[t]{2}{*}{ Full } & Interacted & $\begin{array}{l}0.0119 * * * \\
(4.35)\end{array}$ & $\begin{array}{l}-0.0021^{* * *} \\
(-3.58)\end{array}$ & $\begin{array}{l}0.0231^{* * *} \\
(4.14)\end{array}$ \\
\hline & $\begin{array}{l}\text { Endogeneity } \\
\text { corrected }\end{array}$ & $\begin{array}{l}0.0114 * * * \\
(2.63)\end{array}$ & $\begin{array}{l}-0.0038 * * * \\
(-4.24)\end{array}$ & $\begin{array}{l}0.0339 * * * \\
(4.61)\end{array}$ \\
\hline \multirow[t]{2}{*}{ Male } & Interacted & $\begin{array}{l}0.0175^{* * *} \\
(4.62)\end{array}$ & $\begin{array}{l}-0.0036^{* * * *} \\
(-4.45)\end{array}$ & $\begin{array}{l}0.0328^{* * * *} \\
(4.12)\end{array}$ \\
\hline & $\begin{array}{l}\text { Endogeneity } \\
\text { corrected }\end{array}$ & $\begin{array}{l}0.0149 * * \\
(2.42)\end{array}$ & $\begin{array}{l}-0.0052^{* * *} \\
(-4.09)\end{array}$ & $\begin{array}{l}0.0439 \\
(4.06)\end{array}$ \\
\hline \multirow[t]{2}{*}{ Female } & Interacted & $\begin{array}{l}0.0026 \\
(0.65)\end{array}$ & $\begin{array}{l}-0.0001 \\
(-0.16)\end{array}$ & $\begin{array}{l}0.0119 \\
(1.54)\end{array}$ \\
\hline & $\begin{array}{l}\text { Endogeneity } \\
\text { corrected }\end{array}$ & $\begin{array}{l}0.0024 \\
(0.39)\end{array}$ & $\begin{array}{l}-0.0019 \\
(-1.49)\end{array}$ & $\begin{array}{l}0.0220^{* *} \\
(2.20)\end{array}$ \\
\hline \multirow[t]{2}{*}{ Union members } & Interacted & $\begin{array}{l}0.0146^{* *} \\
(2.42)\end{array}$ & $\begin{array}{l}-0.0020 \\
(-1.60)\end{array}$ & $\begin{array}{l}0.0066 \\
(0.51)\end{array}$ \\
\hline & $\begin{array}{l}\text { Endogeneity } \\
\text { corrected }\end{array}$ & $\begin{array}{l}0.0272 * * \\
(2.50)\end{array}$ & $\begin{array}{l}-0.0034 \\
(-1.63)\end{array}$ & $\begin{array}{l}0.0149 \\
(0.84)\end{array}$ \\
\hline \multirow[t]{2}{*}{ Nonunion } & Interacted & $\begin{array}{l}0.0096^{* * *} \\
(3.17)\end{array}$ & $\begin{array}{l}-0.0022 * * * \\
(-3.35)\end{array}$ & $\begin{array}{l}0.0241 * * * \\
(3.96)\end{array}$ \\
\hline & $\begin{array}{l}\text { Endogeneity } \\
\text { corrected }\end{array}$ & $\begin{array}{l}0.0087^{*} \\
(1.86)\end{array}$ & $\begin{array}{l}-0.0038 * * * \\
(-3.86)\end{array}$ & $\begin{array}{l}0.0341^{* * *} \\
(4.28)\end{array}$ \\
\hline \multirow[t]{2}{*}{ Age: $16-34$} & Interacted & $\begin{array}{l}0.0058 \\
(1.38)\end{array}$ & $\begin{array}{l}-0.0013 \\
(-1.51)\end{array}$ & $\begin{array}{l}0.0210^{* *} \\
(2.45)\end{array}$ \\
\hline & $\begin{array}{l}\text { Endogeneity } \\
\text { corrected }\end{array}$ & $\begin{array}{l}0.0106 \\
(1.58)\end{array}$ & $\begin{array}{l}-0.0030^{* *} \\
(-2.17)\end{array}$ & $\begin{array}{l}0.0314^{* * *} \\
(2.80)\end{array}$ \\
\hline \multirow[t]{2}{*}{ Age: $35-50$} & Interacted & $\begin{array}{l}0.0111^{* * *} \\
(2.67)\end{array}$ & $\begin{array}{l}-0.0022 * * \\
(-2.45)\end{array}$ & $\begin{array}{l}0.0198^{* *} \\
(2.33)\end{array}$ \\
\hline & $\begin{array}{l}\text { Endogeneity } \\
\text { corrected }\end{array}$ & $\begin{array}{l}0.0019 \\
(0.30)\end{array}$ & $\begin{array}{l}-0.0033^{* *} \\
(-2.43)\end{array}$ & $\begin{array}{l}0.0264^{* *} \\
(2.36)\end{array}$ \\
\hline \multirow[t]{2}{*}{ Age: $51+$} & Interacted & $\begin{array}{l}0.0251 * * * \\
(3.59)\end{array}$ & $\begin{array}{l}-0.0032 * * \\
(-2.07)\end{array}$ & $\begin{array}{l}0.0371^{* * *} \\
(2.61)\end{array}$ \\
\hline & $\begin{array}{l}\text { Endogeneity } \\
\text { corrected }\end{array}$ & $\begin{array}{l}0.0333 * * * \\
(2.85)\end{array}$ & $\begin{array}{l}-0.0071 * * * \\
(-2.91)\end{array}$ & $\begin{array}{l}0.0615^{* * *} \\
(3.23)\end{array}$ \\
\hline
\end{tabular}

The dependent variable is the log of real average wages. Other controls include (when appropriate) gender, marital status, veteran status, race, education, region of residence, age, age squared, indicators for two-digit occupation and year, and metropolitan fixed effects. Regressions are weighted using sample weights. Numbers in parentheses are $t$ statistics. Standard errors for endogeneity-corrected results are robust to heteroskedasticity.

$*, * *$, and $* * *$ indicate significance at the $10 \%, 5 \%$, and $1 \%$ levels, respectively.

potential way is to calculate the state unemployment rate and apply that to anyone outside of a MSA. ${ }^{15}$ Although this will most assuredly not be equal to the local labor market conditions facing rural workers, it does give a sense of the overall health of the state level labor market. Estimates using this sample and methodology are found in Table 5. Again,

\footnotetext{
${ }^{15}$ By including rural workers, the sample now increases to 67,702 respondents. We also tried an alternative specification of the rural unemployment rate as the unemployment rate for the state not including people who live in a metropolitan area. The results from this specification are similar to Table 5.
} 
the same results hold - generally a positive CWD, but a negative coefficient on the interacted variable. ${ }^{16}$

\section{An Application: The Impact on Calculating Implicit Values of Injuries}

An application of the model concerns the use of the CWD estimates in calculating the implicit value of an injury (see Viscusi and Aldy 2003 for a survey of U.S. and international studies). The methodology to calculate the implicit value of an injury is given by the following formula:

$$
\mathrm{VoI}=100 \times \frac{\partial(\ln w)}{\partial R} \times \bar{w} \times 2000
$$

where $\partial(\ln w) / \partial R$ is the estimated CWD and $\bar{w}$ is the average wage. This gives the value of changing the rate by one unit, and so to reduce the probability of injury completely for the average person, this needs to be multiplied by the average risk rate. ${ }^{17}$ The important change here compared to the earlier literature is that $\partial(\ln w) / \partial R$ may vary with the unemployment rate, as the "Interacted" model would indicate.

Table 6 reports the implicit values of an injury (VoI) based on different samples and specifications. For the full sample under the "Simple" specification, the VoI (in 2001 dollars) is $\$ 52,164 .{ }^{18}$ However, when the "Interacted" model is estimated and the unemployment rate is constrained to be zero (that is, assuming there is no effect of unemployment on the compensating differential), the VoI increases substantially to $\$ 114,360$, showing that not controlling for unemployment underestimates the VoI quite substantially.

The pattern for the full sample is repeated for every subsample and specification, where not controlling for risk-unemployment rate interactions causes an underestimate of the VoI evaluated at the extreme case of zero unemployment. The simple VoI for males and females are $\$ 64,907$ and $\$ 12,831$, respectively, while the "Interacted" model (where the unemployment rate is set to zero) gives a $\mathrm{VoI}$ of $\$ 197,125$ and $\$ 25,413$, respectively. For union and nonunion workers, there is also an increase in the VoI, increasing from $\$ 122,671$ and $\$ 133,338$ for union workers and $\$ 9462$ to $\$ 90,835$ for nonunion workers. Finally in each age category the VoI increases: from $-\$ 84$ to $\$ 19,735$ for the $16-34$ age group, from $\$ 40,935$ to $\$ 129,627$ for the $35-$ 50 age group, and from $\$ 188,251$ to $\$ 346,208$ for the $51+$ age group.

However, it is not clear that zero is the most appropriate value for the unemployment rate, and certainly it is not realistic. Using the sample average unemployment rate of $4.4 \%$ (which is

\footnotetext{
${ }^{16}$ As a further robustness check, a series of regressions were also estimated to control for job insecurity. In previous research, job insecurity is generally proxied by the unemployment rate in an industry or occupation. Including unemployment rates recorded at the three-digit industry or occupation level does not affect the CWD and interaction coefficients by any appreciable amount. Results are available in an appendix available from the authors.

${ }^{17}$ Given that different samples are used, the sample specific average wage and injury rates are used in this calculation. These averages are given in the notes of Table 6. This is in the spirit of Leeth and Ruser (2003) who use a similar, but more detailed, methodology.

18 The VoI for the full sample falls into the range (between \$20,000 and \$70,000) that Viscusi and Aldy (2003, p. 35 and Table 5) report, although there are quite a few studies that find VoI estimates over $\$ 100,000$, indicating a fairly wide variation in estimates. The wide variation here for the subsamples is primarily because of the different estimates of the CWD but is also due to differences in average wages and injury rates. So, for example, the high VoI for union workers is a combination of having the highest CWD, average wage, and injury rate.
} 
Table 5. Estimates of CWD by Subsamples, Including Workers Not in an MSA

\begin{tabular}{|c|c|c|c|c|}
\hline \multirow[b]{2}{*}{ Sample } & \multirow[b]{2}{*}{ Model } & \multicolumn{3}{|c|}{ Coefficient on } \\
\hline & & Risk & $\begin{array}{c}\text { Risk*Metro } \\
\text { Unemployment Rate }\end{array}$ & $\begin{array}{c}\text { Metro } \\
\text { Unemployment Rate }\end{array}$ \\
\hline \multirow[t]{2}{*}{ Full } & Interacted & $\begin{array}{l}0.0070 * * * \\
(5.00)\end{array}$ & $\begin{array}{l}-0.0010^{* * * *} \\
(-3.32)\end{array}$ & $\begin{array}{l}0.0086 * * * \\
(3.11)\end{array}$ \\
\hline & $\begin{array}{c}\text { Endogeneity } \\
\text { corrected }\end{array}$ & $\begin{array}{l}0.0063^{* * *} \\
(2.77)\end{array}$ & $\begin{array}{l}-0.0021 * * * \\
(-4.43)\end{array}$ & $\begin{array}{l}0.0154^{* * *} \\
(4.06)\end{array}$ \\
\hline \multirow[t]{2}{*}{ Male } & Interacted & $\begin{array}{l}0.0085^{* * *} \\
(3.91)\end{array}$ & $\begin{array}{l}-0.0014 * * * \\
(-3.03)\end{array}$ & $\begin{array}{l}0.0078^{*} \\
(1.81)\end{array}$ \\
\hline & $\begin{array}{c}\text { Endogeneity } \\
\text { corrected }\end{array}$ & $\begin{array}{l}0.0043 \\
(1.21)\end{array}$ & $\begin{array}{l}-0.0023^{* * * *} \\
(-3.25)\end{array}$ & $\begin{array}{l}0.0141^{* *} \\
(2.35)\end{array}$ \\
\hline \multirow[t]{2}{*}{ Female } & Interacted & $\begin{array}{l}0.0020 \\
(0.88)\end{array}$ & $\begin{array}{l}-0.0003 \\
(-0.62)\end{array}$ & $\begin{array}{l}0.0061 \\
(1.50)\end{array}$ \\
\hline & $\begin{array}{c}\text { Endogeneity } \\
\text { corrected }\end{array}$ & $\begin{array}{l}0.0020 \\
(0.56)\end{array}$ & $\begin{array}{l}-0.0019 * * * \\
(-2.67)\end{array}$ & $\begin{array}{l}0.0155^{* * *} \\
(2.92)\end{array}$ \\
\hline \multirow[t]{2}{*}{ Union members } & Interacted & $\begin{array}{l}0.0084^{* *} \\
(2.23)\end{array}$ & $\begin{array}{l}-0.0005 \\
(-0.74)\end{array}$ & $\begin{array}{l}-0.0081 \\
(-1.06)\end{array}$ \\
\hline & $\begin{array}{c}\text { Endogeneity } \\
\text { corrected }\end{array}$ & $\begin{array}{l}0.0111 \\
(1.64)\end{array}$ & $\begin{array}{l}-0.0005 \\
(-0.38)\end{array}$ & $\begin{array}{l}-0.0091 \\
(-0.92)\end{array}$ \\
\hline \multirow[t]{2}{*}{ Nonunion } & Interacted & $\begin{array}{l}0.0049 * * * \\
(2.87)\end{array}$ & $\begin{array}{l}-0.0010^{* * *} \\
(-2.88)\end{array}$ & $\begin{array}{l}0.0091 * * * \\
(2.83)\end{array}$ \\
\hline & $\begin{array}{c}\text { Endogeneity } \\
\text { corrected }\end{array}$ & $\begin{array}{l}0.0033 \\
(1.26)\end{array}$ & $\begin{array}{l}-0.0022 * * * \\
(-4.16)\end{array}$ & $\begin{array}{l}0.0164 \\
(3.85)\end{array}$ \\
\hline \multirow[t]{2}{*}{ Age: 16-34 } & Interacted & $\begin{array}{l}0.0013 \\
(0.55)\end{array}$ & $\begin{array}{l}-0.0003 \\
(-0.67)\end{array}$ & $\begin{array}{l}0.0027 \\
(0.59)\end{array}$ \\
\hline & $\begin{array}{c}\text { Endogeneity } \\
\text { corrected }\end{array}$ & $\begin{array}{l}0.0049 \\
(1.33)\end{array}$ & $\begin{array}{l}-0.0016^{* *} \\
(-2.20)\end{array}$ & $\begin{array}{l}0.0111^{*} \\
(1.80)\end{array}$ \\
\hline \multirow[t]{2}{*}{ Age: $35-50$} & Interacted & $\begin{array}{l}0.0054^{* *} \\
(2.21)\end{array}$ & $\begin{array}{l}-0.0009 * \\
(-1.67)\end{array}$ & $\begin{array}{l}0.0095 * * \\
(2.00)\end{array}$ \\
\hline & $\begin{array}{c}\text { Endogeneity } \\
\text { corrected }\end{array}$ & $\begin{array}{l}-0.0037 \\
(-0.98)\end{array}$ & $\begin{array}{l}-0.0016^{* *} \\
(-2.06)\end{array}$ & $\begin{array}{l}0.0138^{* *} \\
(2.24)\end{array}$ \\
\hline \multirow[t]{2}{*}{ Age: $51+$} & Interacted & $\begin{array}{l}0.0178 * * * \\
(4.64)\end{array}$ & $\begin{array}{l}-0.0020^{* *} \\
(-2.55)\end{array}$ & $\begin{array}{l}0.0156^{* *} \\
(2.17)\end{array}$ \\
\hline & $\begin{array}{c}\text { Endogeneity } \\
\text { corrected }\end{array}$ & $\begin{array}{l}0.0175^{* * *} \\
(2.85)\end{array}$ & $\begin{array}{l}-0.0039 * * \\
(-3.27)\end{array}$ & $\begin{array}{l}0.0270 * * * \\
(2.91)\end{array}$ \\
\hline
\end{tabular}

The dependent variable is the log of real average wages. Other controls include (when appropriate) gender, marital status, veteran status, race, education, region of residence, age, age squared, indicators for two-digit occupation and year, and metropolitan fixed effects. Regressions are weighted using sample weights. Numbers in parentheses are $t$ statistics. Workers not in a MSA are given the unemployment rate for the state in which they live. Standard errors for endogeneity corrected results are robust to heteroskedasticity.

$*, * *$, and $* * *$ indicate significance at the $10 \%, 5 \%$, and $1 \%$ levels, respectively.

close to the estimated nonaccelerating inflation rate of unemployment [NAIRU] for the late 1990s and early 2000s according to Ball and Mankiw 2002 and Clemente, Lanaspa, and Montañés 2005, although the latter article finds a good deal of dispersion of the NAIRU across states) we find in the final row of each subsample that the VoI adjusted for this average unemployment rate is fairly close to the VoI that comes from the "Simple" model. So, for example, the VoI drops to $\$ 59,618$ for men and $\$ 11,548$ for women. This pattern of being within a couple hundred dollars of the "Simple" model estimates is repeated for each subsample. 
Table 6. Estimates of Implicit Value of Injury

\begin{tabular}{|c|c|c|c|}
\hline Sample & Model & $\begin{array}{l}\text { Implicit Value of } \\
\text { Injury (VoI) }\end{array}$ & $\begin{array}{l}\text { Change in VoI for a } \\
\text { One-Point Increase in the UR }\end{array}$ \\
\hline \multirow[t]{3}{*}{ Full } & Simple & $\$ 52,164$ & \\
\hline & Interacted $(\mathrm{UR}=0)$ & 114,360 & $\$-14,044$ \\
\hline & Interacted $(\mathrm{UR}=4.4)$ & 52,566 & \\
\hline \multirow[t]{3}{*}{ Male } & Simple & 64,907 & \\
\hline & Interacted $(\mathrm{UR}=0)$ & 197,125 & $-31,251$ \\
\hline & Interacted $(\mathrm{UR}=4.4)$ & 59,618 & \\
\hline \multirow[t]{3}{*}{ Female } & Simple & 12,831 & \\
\hline & Interacted $(\mathrm{UR}=0)$ & 25,661 & -3208 \\
\hline & Interacted $(\mathrm{UR}=4.4)$ & 11,548 & \\
\hline \multirow[t]{3}{*}{ Union members } & Simple & 122,671 & \\
\hline & Interacted $(\mathrm{UR}=0)$ & 133,338 & -2667 \\
\hline & Interacted $(\mathrm{UR}=4.4)$ & 121,604 & \\
\hline \multirow[t]{3}{*}{ Nonunion } & Simple & 9462 & \\
\hline & Interacted $(\mathrm{UR}=0)$ & 90,835 & $-18,924$ \\
\hline & Interacted $(\mathrm{UR}=4.4)$ & 7570 & \\
\hline \multirow[t]{3}{*}{ Age $16-34$} & Simple & -84 & \\
\hline & Interacted $(\mathrm{UR}=0)$ & 19,735 & -4934 \\
\hline & Interacted $(\mathrm{UR}=4.4)$ & -1973 & \\
\hline \multirow[t]{3}{*}{ Age $35-50$} & Simple & 40,935 & \\
\hline & Interacted $(\mathrm{UR}=0)$ & 129,627 & $-20,467$ \\
\hline & Interacted $(\mathrm{UR}=4.4)$ & 39,570 & \\
\hline \multirow[t]{3}{*}{ Age $51+$} & Simple & 188,251 & \\
\hline & Interacted $(\mathrm{UR}=0)$ & 346,208 & $-36,785$ \\
\hline & Interacted $(\mathrm{UR}=4.4)$ & 184,356 & \\
\hline
\end{tabular}

Value of injury and change in VoI based on the CWD estimates in Table 1. Average real hourly wage data for full, male, female, union, nonunion, age $16-34$, age $35-50$, and age $51+$ samples are $\$ 16.18, \$ 17.94, \$ 14.32, \$ 18.78, \$ 15.77$, $\$ 13.48, \$ 18.34$, and $\$ 17.45$, respectively. The mean risk rates are 6.2, 6.7, 5.6, 7.1, 6.0,6.1, 6.2, and 6.2, respectively.

This might cast some doubt about whether the methodology described here is actually worth doing if the ultimate aim was to calculate an average VoI. However, the importance of the bias in the VoI comes in when the unemployment rate is significantly above this average (i.e., above the NAIRU for this time period). The easiest way to see this is to use the interaction term to indicate how much the estimated VoI falls for a one percentage point increase in the unemployment rate. For example, for the full sample, the estimated VoI falls by $\$ 14,044$ for each percentage point the local unemployment rate increases, meaning that an unemployment rate of $8.14 \%$ reduces the $\mathrm{VoI}$ to zero. This is the case for approximately $4.9 \%$ of the sample who reside in areas with unemployment rates above that threshold. The reduction in the VoI for the subsamples ranges from $\$ 3208$ for females to $\$ 31,251$ for males, is greater for nonunion workers, and is increasing with age. These reductions mean that the VoI is eliminated when the unemployment rate ranges from $4 \%$ (for the 16-34 age group) to $9.41 \%$ (for workers over age 50). ${ }^{19}$

\footnotetext{
${ }^{19}$ For union workers the unemployment rate needs to reach over $50 \%$, which is clearly unrealistic, but as mentioned above, collective bargaining may cause wages not to be tied closely to CWD or unemployment rates very closely.
} 


\section{Conclusions and Future Work}

The theory of compensating wage differentials is one that makes intuitive sense, but the implications of the theory depend crucially on an efficiently functioning labor market. Indeed, a simple model is developed to show that when labor markets are not operating efficiently, firms are no longer forced to offer as high of a compensating differential for disamenities and that the CWD will, therefore, be smaller in less efficient markets. This implies that estimating the CWD for a disamenity using cross-sectional data will cause a downward bias in the estimate if the cross sections span labor markets with different efficiency. Using standard data for the estimation of the CWD for risk, this study shows that the bias is quite large, resulting in a much larger estimated CWD when an interaction between injury risk and unemployment is taken into account. An application to the implicit value of an injury is also estimated to show that the bias can affect these estimates as well.

Future work should focus on whether these relationships found here are also present in other subsamples of the data and are robust to other types of corrections for endogeneity and measurement error. In addition, theoretically, the implications of this article will likely hold for other types of compensating wage differentials. In any labor market where the probability of not working is relatively large, firms will try to reduce the higher compensating pay for disamenities in an effort to reduce costs. It would be interesting to see if the reductions in the estimated CWD because of unemployment occur in similar magnitudes for these other disamenities. It may well be the case that it is harder to reduce, for example, the CWD for fatal risk than for injury risk.

\section{Appendix 1:}

Means of the Variables

\begin{tabular}{lcccccccc}
\hline Variable & $\begin{array}{c}\text { Full } \\
\text { Sample }\end{array}$ & $\begin{array}{c}\text { Male } \\
\text { Sample }\end{array}$ & $\begin{array}{c}\text { Female } \\
\text { Sample }\end{array}$ & $\begin{array}{c}\text { Union } \\
\text { Sample }\end{array}$ & $\begin{array}{c}\text { Nonunion } \\
\text { Sample }\end{array}$ & $\begin{array}{c}\text { Age: } \\
16-34\end{array}$ & $\begin{array}{c}\text { Age: } \\
35-50\end{array}$ & $\begin{array}{c}\text { Age: } \\
51+\end{array}$ \\
\hline Real hourly wage & $\$ 16.18$ & $\$ 17.94$ & 14.32 & 18.78 & 15.77 & 13.48 & 18.34 & 17.45 \\
Log hourly wage & 2.601 & 2.705 & 2.491 & 2.814 & 2.567 & 2.428 & 2.742 & 2.673 \\
Injury rate & 6.169 & 6.682 & 5.623 & 7.131 & 6.015 & 6.105 & 6.223 & 6.191 \\
Metro unemployment & 4.357 & 4.360 & 4.354 & 4.559 & 4.325 & 4.371 & 4.354 & 4.335 \\
Male & 0.515 & 1.000 & 0.000 & 0.575 & 0.506 & 0.522 & 0.514 & 0.503 \\
Married & 0.567 & 0.596 & 0.537 & 0.646 & 0.555 & 0.392 & 0.685 & 0.701 \\
Veteran & 0.097 & 0.177 & 0.012 & 0.142 & 0.090 & 0.039 & 0.093 & 0.243 \\
White & 0.826 & 0.843 & 0.807 & 0.809 & 0.828 & 0.808 & 0.829 & 0.860 \\
Black & 0.121 & 0.103 & 0.141 & 0.150 & 0.117 & 0.135 & 0.119 & 0.097 \\
High school diploma & 0.294 & 0.296 & 0.292 & 0.342 & 0.286 & 0.274 & 0.298 & 0.331 \\
Some college & 0.301 & 0.284 & 0.318 & 0.293 & 0.302 & 0.327 & 0.295 & 0.255 \\
Bachelor's degree & 0.201 & 0.196 & 0.207 & 0.158 & 0.208 & 0.206 & 0.213 & 0.164 \\
Graduate degree & 0.093 & 0.097 & 0.090 & 0.128 & 0.088 & 0.052 & 0.116 & 0.138 \\
Age & 38.3 & 38.2 & 38.5 & 42.0 & 37.7 & 26.4 & 42.4 & 57.3 \\
Age squared & 1619.3 & 1606.9 & 1632.7 & 1887.6 & 1576.5 & 721.3 & 1787.9 & 3320.4 \\
Northeast region & 0.204 & 0.200 & 0.207 & 0.271 & 0.193 & 0.190 & 0.214 & 0.209 \\
North-central region & 0.229 & 0.228 & 0.229 & 0.305 & 0.217 & 0.224 & 0.231 & 0.233 \\
West region & 0.234 & 0.240 & 0.228 & 0.252 & 0.231 & 0.241 & 0.235 & 0.215 \\
Southern region & 0.334 & 0.332 & 0.336 & 0.172 & 0.360 & 0.345 & 0.319 & 0.342 \\
Number of & 42,429 & 21,698 & 20,731 & 5959 & 36,470 & 16,969 & 17,666 & 7794 \\
$\quad$ observations & & & & & & & & \\
\hline
\end{tabular}

Source: Sociodemographic data are from the 1996-2001 March CPS (Annual Demographic Survey), excluding observations with imputed earnings. Averages are weighted using CPS sample weights. Injury risk data are from the Bureau of Labor Statistics. 


\section{References}

Abowd, John, and Orley Ashenfelter. 1984. Anticipated unemployment, temporary layoffs and compensating differentials. In Studies in labor markets, edited by Sherwin Rosen. Chicago: University of Chicago Press, pp. 141-70.

Assad, Ragui, and Insan Tunali. 2002. Wage formation and recurrent unemployment. Labour Economics 9:17-61.

Averette, Susan, Howard Bodenhorn, and Justas Staisiunas. 2005. Unemployment risk and compensating differentials in New Jersey manufacturing. Economic Inquiry 43:734 49.

Ball, Laurence, and N. Gregory Mankiw. 2002. The NAIRU in theory and practice. Journal of Economic Perspectives 16:115-36.

Bender, Keith A., Hosne Mridha, and James Peoples. 2006. Risk compensation for hospital workers: Evidence from relative wages of janitors. Industrial and Labor Relations Review 59:226-42.

Berger, Mark C., Glenn Blomquist, and Klara Sabiranova Peter. 2008. Compensating differentials in emerging labor and housing markets: Estimates of quality of life in Russian cities. Journal of Urban Economics 63:25-55.

Black, Dan A., and Thomas J. Kniesner. 2003. On the measurement of job risk in hedonic wage models. Journal of Risk and Uncertainty 27:205-20.

Blanchflower, David A., and Andrew J. Oswald. 1994. The wage curve. Cambridge, MA: MIT Press.

Bollinger, Christopher R., and Barry T. Hirsch. 2006. Match bias from earnings imputation in the Current Population Survey: The case of imperfect matching. Journal of Labor Economics 24:483-519.

Clemente, Jesús, Luis Lanaspa, and Antonio Montañés. 2005. The unemployment structure of the U.S. states. Quarterly Review of Economics and Finance 45:848-68.

Dorman, Peter, and Paul Hagstrom. 1998. Wage compensation for dangerous work revisited. Industrial and Labor Relations Review 52:116-35.

Garen, John. 1988. Compensating differentials and the endogeneity of job riskiness. Review of Economics and Statistics 70:9-16.

Hamermesh, Daniel S., and John R. Wolfe. 1990. Compensating wage differentials and the duration of wage loss. Journal of Labor Economics 8:S175-97.

Harris, John R., and Michael P. Todaro. 1970. Unemployment \& development: A two-sector analysis. American Economic Review 60:126-42.

Hatton, Timothy J., and Jeffrey G. Williamson. 1991. Unemployment, employment contracts, and compensating wage differentials: Michigan in the 1890s. Journal of Economic History 51:605-32.

Heckman, James J. 1979. Sample selection bias as a specification error. Econometrica 47:153-61.

Hersch, Joni. 1998. Compensating differentials for gender-specific job injury risks. American Economic Review 88:598-607.

Hirsch, Barry T., and Edward J. Schumacher. 2004. Match bias in wage gap estimates due to earnings imputation. Journal of Labor Economics 22:689-722.

Hutchens, Robert M. 1983. Layoffs and labor supply. International Economic Review 24:37-55.

Lang, Kevin, and Sumon Majumdar. 2004. The pricing of job characteristics when markets do not clear: Theory and policy implications. International Economic Review 45:1111-28.

Leeth, John D., and John Ruser. 2003. Compensating wage differentials for fatal and nonfatal injury risk by gender and race. Journal of Risk and Uncertainty 27:257-77.

Manning, Alan. 2003. Monopsony in motion: Imperfect competition in labor markets. Princeton: Princeton University Press.

Mrozek, Janusz R., and Laura O. Taylor. 2002. What determines the value of life? A meta-analysis. Journal of Policy Analysis and Management 21:253-70.

Purse, Kevin. 2004. Work-related fatality risks and neoclassical compensating wage differentials. Cambridge Journal of Economics 28:597-617.

Robinson, James C. 1988. The rising long-term trend in occupational injury rates. American Journal of Public Health 78:276-81.

Rosen, Sherwin. 1986. The theory of equalizing differences. In Handbook of labor economics, edited by Orley Ashenfelter and David Card. Amsterdam: North-Holland, pp. 641-92.

Sandy, Robert, and Robert F. Elliot. 1996. Unions and risk: Their impact on the level of compensation for fatal risk. Economica 63:291-309.

Sandy, Robert, and Robert F. Elliott. 2005. Long-term illness and wages: The impact of the risk of occupationally related long-term illness on earnings. Journal of Human Resources 40:744-68.

Sandy, Robert, Robert F. Elliott, W. Stanley Siebert, and Xiangdong Wei. 2001. Measurement error and the effects of unions on the compensating differentials for fatal workplace risks. Journal of Risk and Uncertainty 23:33-56.

Todaro, Michael P. 1969. A model for labor migration and urban unemployment in less developed countries. American Economic Review 59:138-48. 
Topel, Robert H. 1984. Equilibrium earnings, turnover, and unemployment: New evidence. Journal of Labor Economics 2:500-522.

Viscusi, W. Kip. 1993. The value of risks to life and health. Journal of Economic Literature 31:1912-46.

Viscusi, W. Kip., and Joseph E. Aldy. 2003. The value of a statistical life: A critical review of market estimates throughout the world. Journal of Risk and Uncertainty 27:5-76.

Winter-Ebmer, Rudolf. 2001. Firm size, earnings, and displacement risk. Economic Inquiry 39:474-86.

Wooldridge, Jeffrey. Lecture notes 8: cluster and stratified sampling. NBER Summer Institute, 2007. Accessed March 2009. Available at http://www.nber.org/WNE/lect_8_cluster.pdf. 
Reproduced with permission of the copyright owner. Further reproduction prohibited without permission. 